\title{
A Comparative Study on Higher Vocational Education for Construction Engineering Technology Majors in China and Australia
}

\author{
Yuan-Yuan Li \\ Chongqing Jianzhu College, Chongqing 400072, China \\ anan5513@163.com
}

\begin{abstract}
Keywords: Higher Vocational Education System, Construction Engineering Technology Majors, Curriculum Design, Evaluation of Teaching Quality.
\end{abstract}

\begin{abstract}
Through the comparison of higher vocational education system and curriculum design for construction engineering technology majors in China and Australia, this paper aims to reflect on the problems of engineering education in Chinese vocational colleges. By learning from the experience of vocational education in Australia, we can explore ways suitable for the development of Chinese vocational education.
\end{abstract}

\section{Introduction}

At present, the competition in Chinese and foreign construction industry is fierce. The reform and innovation of construction technology is closely related to the development of construction industry and national economic power. Colleges with construction engineering technology majors undertake the important task of training engineering and technical personnel. The higher engineering education in Australia is in a leading position in the world, which covers vocational training, college education and occupational accreditation system[1]. Chinese higher engineering education needs to learn from the advanced experience of Australia, explore the ways to improve theory of education, curriculum design and talents training.

\section{The Comparison of Higher Vocational Education System in China and Australia}

With the adjustment of world economic and industrial structure, our society needs not only academic talents with theoretical knowledge, but also a large number of talents with technical skills. This situation brings opportunities for development of vocational education. In recent years, higher vocational education develops rapidly. Countries all around the world have gradually formed various educational systems with their own characteristics.

\subsection{Higher Vocational Education System in Australia}

After more than 100 years' development, Australian vocational education has formed a unique pattern. TAFE (Technical and Further Education) is a unique system for vocational education and training in Australia, and it is the main provider for the national Vocational Education and Training (VET). It is also an important part of Australian higher education system. It combines the technical education with the continuing education, linking up academic qualifications to job training.

TAFE is a well-developed system of vocational education in Australia, and the employment rate of its graduates is very high. TAFE courses cover thousands of vocational courses and general courses. The curriculum design is oriented by employment, so as to meet the needs of social economy and business development. Many courses can also be linked with the courses in university for continuing learning. TAFE teachers are mostly professionals, who integrate classroom teaching with practical training. In various fields of industries in Australia, the TAFE diploma is recognized by almost all employers. TAFE graduates are taught with practical skills that can be applied to their jobs, so they can adapt to the work quickly.

\subsection{Higher Vocational Education System in China}

Since 1998, the development of higher vocational education in China has been on the rise. The number of vocational colleges and enrollment increased year by year. The categories of subjects in vocational colleges cover various types of occupation and profession that suit the needs of modernization. 
In China, vocational colleges have gradually highlighted the work-integrated learning, and established the education mode of school-enterprise cooperation. At the same time, the system of double certificate (academic certificate and professional certificate) is actively pursued, and a relatively independent system for practical teaching has been set up.

Despite the rapid development of higher vocational education in China, there are still a lot of problems and difficulties. The social position of the front line workers is low, and the society does not attach importance to vocational education. In addition, the national financial investment for higher vocational education is obviously less than that of common universities and colleges.

\section{A Comparison of Curriculum Design for Construction Engineering Technology Majors in China and Australia}

\subsection{The Curriculum Design for Construction Engineering Technology Majors in Australia}

The courses for construction engineering technology majors in Australia are guided by the construction industry. The organizations of construction industry are responsible for developing the curriculum content and readjusting the courses. The National Council of Construction Industry would discuss with its consulting organizations on the employment market and job skills requirements based on the needs of the construction industry, and then report to the Education and Training Department of each state for approval[2]. The specific content of the courses for construction majors can be selected and set jointly by the enterprises, construction groups and colleges, so as to ensure they are well-directed.

The accreditation of construction professional qualification is based on a unified national qualification framework, including six vocational qualification certificates for construction majors ( Level-I to Level-IV Certificate, General Diploma, Higher Diploma). In order to obtain a Level-I certificate, students should complete all the courses in 4-6 months, and the courses aim to train the operator. To get a Level- II certificate, students will be trained for 6-8 months, which aim to train senior operator. The study time for obtaining Level-III certificate costs 12 months, which is to train qualified technicians. To obtain a Level-IV certificate, students should be trained for 12-18 months, and it aims to train supervisor. The training for obtaining General Diploma costs 18-24 months, which aims to train the professional-to-be. And the study time for obtaining Higher Diploma is 24-36 months, aiming to train junior manager[3]. Students can get credits according to their own needs at any time, and those who get the diploma can directly enter university for further learning.

\subsection{The Curriculum Design for Construction Engineering Technology Majors in China}

In Chinese vocational colleges, the students of construction majors mainly graduated from ordinary high school, vocational school and technical school. They know little about the professional knowledge of the construction industry. So the vocational colleges offer them theoretical courses and professional practice courses. By learning the theoretical courses, students can master the necessary knowledge of the construction industry, and understand the job needs. College-Enterprise cooperation sets the stage for practical training for students. Through the practice course, students can experience the working environment for their future job.

With College-Enterprise cooperation, the practice courses integrate with the job requirements of construction enterprises, aiming to cultivate students' practical ability, such as engineering cartography, the application of AutoCAD, experimental operation, engineering survey etc.. The practice courses mainly include theoretical study (such as construction organization, structure of reinforced concrete, etc.), experiments in the lab (such as test for compressive strength and tensile force of concrete component, mechanical properties tests for reinforcing steel, asphalt penetration test etc.), on-campus training (such as learning construction materials, construction structure etc.), off-campus training (laying-out survey on site, measurement, drawing, etc.)[4]. The practice courses can help students to deepen their understanding of theoretical knowledge, and improve their ability to operate. 


\section{The Enlightenment of Australian Higher Engineering Education for China}

The rapid development of China's market economy leads to the expansion of the demand for engineers. College engineering graduates are also increasing year by year. Although China's higher engineering education has made great achievements, there are still many problems: (1) Lack of a sound evaluation system. The evaluation mode of higher education in China is centralized, which has long been dominated by the Ministry of Education, and the evaluation criteria are divorced from reality of enterprises. (2) Lack of teachers with double qualifications. In vocational colleges, teachers have much theoretical knowledge, but lack practical ability; in addition, China has not yet established a specific evaluating and training system for vocational college teachers.

\subsection{The Establishment of Teaching Evaluation System}

According to the requirements of Australian Engineering Association, the professionals can be directly involved in the students' courses, work practice and graduate recruitment. Most engineering students will be asked to spend 50\% of their time working on engineering projects. Australian higher education uses the credit system, and the credits earned by students are recognized in high school, TAFE college and university. Students who completed the study of courses and got the credits can further obtain a diploma or certificate. The quality guarantee system of higher education in Australia is jointly operated by the federal government of Australia (including the government of state or special administrative region), Australian Qualifications Framework (AQF), Australian University Quality Agency (AUQA) and the universities[5].

The proficiency judgment for Chinese vocational college students are in accordance with the examination results for each course, and the examination would be carried out just once. In Australia, there are three rounds of tests for each course, the first round is to test the basic knowledge, the second is application, and the third is to test comprehensive ability. When the students are recommended to the employers, their ability will be judged by the three results; and it also determines their job position and salary[6]. In summary, Chinese higher vocational education needs to learn from the experience of Australia, and constantly improve its own evaluation system, working on creating and using new methods to encourage the students to learn actively.

\subsection{Team Building of the Teaching Staff}

The Australian vocational education insists on strict requirements for teachers. To become a qualified teacher of vocational education, they are required to have 3-5 years' working experience in the related industry. Such teachers can not only do theory lecturing but also practical training. For example, the headmaster of Regency Hotel School is a professional who has 10 years' working experience as a hotel manager. The strictly regulated hiring process in Australia further ensures the high standard of vocational education teachers.

The Chinese vocational college teachers need to change their perception of education, and understand that the essence of higher vocational education is practice. In their spare time, they have to improve occupational skills. Vocational colleges also need to enlarge the teaching staff from diversified sources. They should not only recruit college graduates as teachers, but also hire some technical personnel with rich practical experience from enterprises; meanwhile, famous experts should be invited to give lectures on advanced knowledge of science and technology, so as to cultivate students' occupation accomplishment, business philosophy and professional skills. The certification system of "double qualification" teachers should be gradually established, so that the team building of vocational college teachers will be standardized and professional.

\section{Conclusion}

The ultimate goal of vocational education is to provide technical talents for the industry and enterprises. Chinese vocational education should draw lessons from the experience of higher engineering education in Australia. Vocational colleges should improve teachers' admittance system, pay more attention to teachers' front-line work experience of construction, management etc., and strive to build a high quality teachers' team. In addition, the specialized teaching evaluation 
institution should be set up. Experts can be organized to develop a specific assessment system, so as to measure the evaluation standard of teaching quality, and gradually improve the evaluation status in vocational colleges. The development of higher vocational education is related to the team building of teaching staff and the teaching quality assessment. Only by actively exploring all kinds of measures to improve the quality of teaching, can we facilitate the sound and sustainable development of Chinese vocational education.

\section{Acknowledgement}

This work was supported by the Research Project of Teaching Reform of Higher Education in Chongqing: A Comparative Study on the Curriculum Design for Construction Engineering Technology Majors of Vocational Colleges in China and Australia (No. 153295).

\section{References}

[1] Jing Zhou, Ai-huang Guo, The Enlightenment of Australian Higher Engineering Education, Computer Education, 21 (2012) 98-102.

[2] Australian Government: Department of Education, Science and Training: Skilling Australia: New Directions for Vocational Education and Training (2005)

[3] Australian Qualifications Framework. http://www.aqf.edu.au/

[4] Shen Bao, Study on the Practice of School-Enterprise Cooperation of the Major of Construction Engineering Technology of Higher Vocational Education in China, the Master's Thesis of Central South University, 12(2012) 21- 22.

[5]Australian Qualifications Framework Advisory Board(AQFAB), Australian Qualifications Framework Implementation Handbook, Melbourne, 2002.

[6] You-qing Li, The Difference Between the System of TAFE Education in Australia and the System of Higher Technical Education in China, Journal of Xiaogan Vocational Technical College, 6(2003), 5-8. 